\title{
Study on fault signal characteristics of an induction motor during interturn fault
}

\author{
Surakit Thongsuk ${ }^{\mathrm{a},{ }^{*}}$, and Atthapol Ngaopitakkul ${ }^{\mathrm{a}}$ \\ ${ }^{a}$ Faculty of Engineering, King Mongkut's Institute of Technology Ladkrabang, Bangkok 10520, Thailand \\ *Corresponding Author: t surakit@hotmail.com, knatthap@kmitl.ac.th
}

\begin{abstract}
This paper aims to measure and analyze the behavior of the fault current when the interturn fault occurs between turns in three-phase induction motors. A 3-HP induction motor is used in the experiment setup to study the effects of a short circuit during the interturn fault occurrence. For induction motor, the winding of induction motor is divided into 5 positions so that the interturn fault signals can be obtained. The results from interturn fault characteristics study shown that current waveform during interturn fault has a sudden change and increases in short period of time. In addition, when interturn fault occurs, the size of load and length of gap are influential factors that affect fault current, not the position of fault. Finally, the results obtained from the analysis will be beneficial in the development of a fault detection scheme.
\end{abstract}

Keywords: Induction motor, Inter-turn stator fault, fault detection.

\section{Introduction}

Currently, the three phase induction motor is widely used; its performance has been developed far more than its predecessor and becomes a popular device in industrial sector. However, the inspection and maintenance are necessary for the induction motor to keep the motor's performance and durability in high level. The regular examination and analysis of any problems or abnormalities that may be occurred in motor are required to ensure that the motor is in workable condition.

The failure of coil's insulator is one of those problems. Firstly, it will cause a turn-to-turn short circuit (interturn fault) and then it will spread to coil-to-coil short circuit, then phase-to-phase short circuit and, lastly, a coil-to-ground short circuit. To overcome the problem before causing more serious problems, the characteristics of fault current are necessary to study the precise protection scheme including to improve a performance of induction motor. In the past decade, the several literatures have been proposed ${ }^{(1-21)}$ about characteristics of fault signals for the induction motor. Many researches have attempted to model and analyze the impact of motor failure and they show that one of the most damage occurring in a three-phase induction motor is the interturn fault, which can occur in every position. It is necessary to understand fault behavior before performing a decision algorithm. Therefore, this paper focuses on the behavior of interturn fault in the three phase induction motor. The single fault is performed using the experimental setup with the 3-HP induction motor. In addition, the winding of induction motor is divided into 5 positions along the length of winding so that the interturn fault signals can be obtained. In addition, the various case studies were performed by changing the position of fault, the length of fault gap including varying the mechanical load.

\section{Experimental Setup and Results}

In this paper, the 3-HP induction motor is performed as the experimental setup for generating the interturn fault signal. The single line diagram of the experimental setup is shown in Fig. 1. By considering Fig. 1, the supply voltage is the three-phase balanced supply using the 3-phase variable auto-transformer as shown in Fig. 2(a). For the next, the winding of induction motor is divided into 5 positions as shown in Fig. 2(b). To implement the interturn fault, the fault control with magnetic contractor is performed as shown in Fig. 2(c). 
Fault patterns in the experimental setup are performed with following changes of the system parameters:

- Coil that fault occurs is coil U, coil V, and coil W

- Fault position of winding is splited as position 1, 2, 3,
4, and 5 and measured from the line end of each coil.

- Length of winding fault gap is divided into 3 steps and measured from the fault position of winding of each coil.

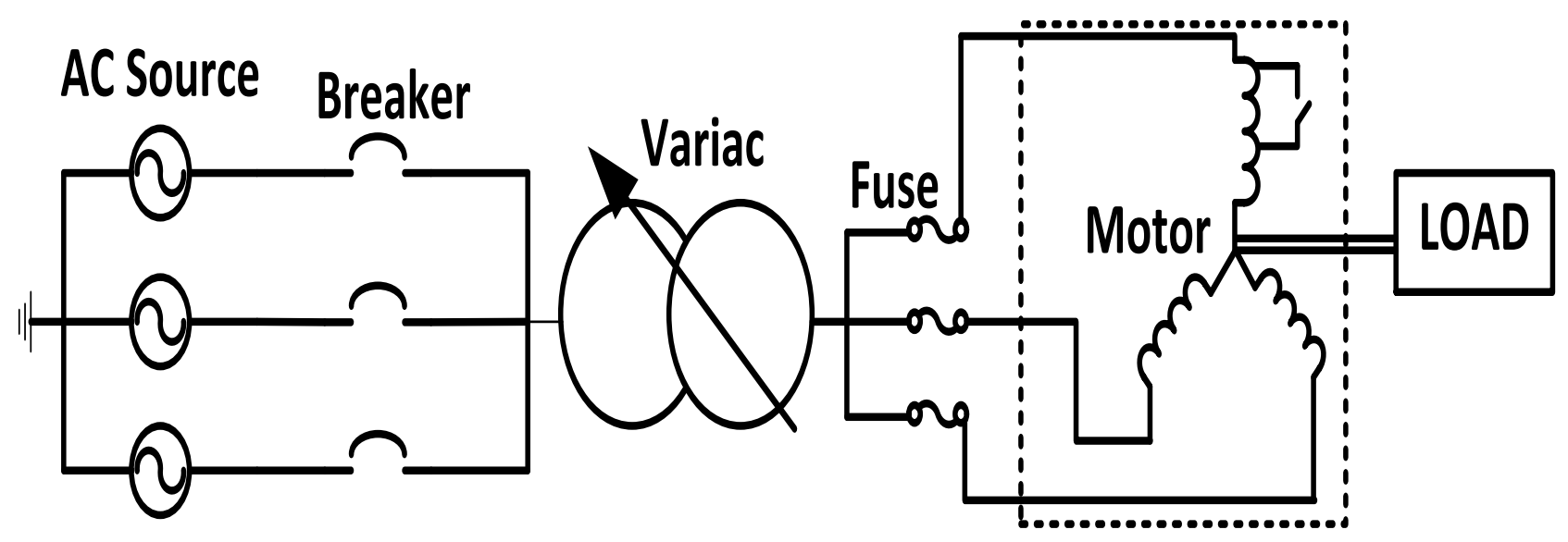

Fig. 1. Single line diagram of experimental setup

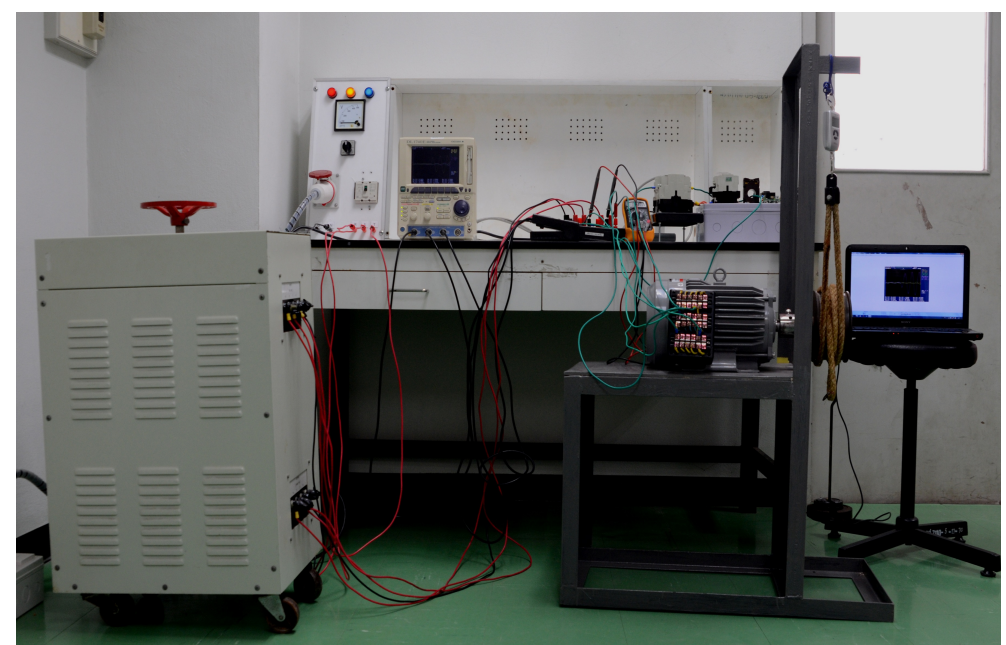

(a) Overall experimental setup

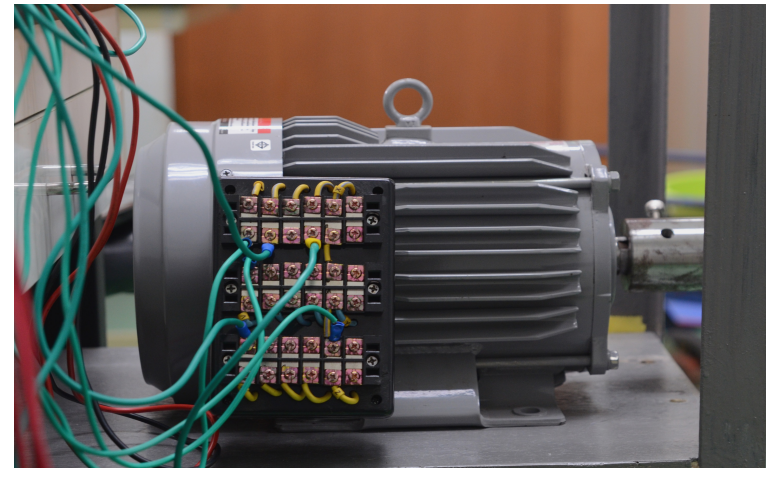

(b) The winding terminals for interturn fault

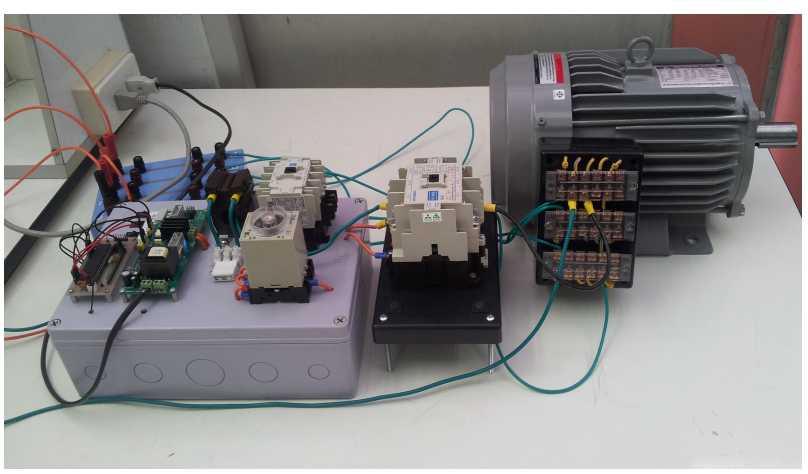

(c) Fault control

Fig. 2. Experimental setup with motor and fault control 
The fault current signals obtained from the experimental setup are shown in Table 1 and Fig. 3. By observing Fig. 3., to understand fault behavior when the interturn fault occurs, the length of fault gap is varied with the increase of each step of 1 as shown in Fig. 3(a), 3(c), 3(e) while the fault position is also varied from position 1 to position 2 as shown in Fig. 3(b), 3(d), 3(f). By considering Fig. 3(a), when the interturn fault occurring between position No. 1 and No. 2 (the length of fault gap is step 1) that is considered as an example, it can be observed that, the switch of fault control is initially be opened, and then closing the switch of fault control so that the amplitude of current signal changes immediately on the faulty coil after the fault occurrence. This indicates that the fault detection decision algorithm works correctly and is beneficial. For the other position of interturn fault (fault between position No. 2 and No. 3 that the length of fault gap is also step 1) that is taken in consideration as shown in Fig. 3(b), it can be seen that the root mean square current $\left(\mathrm{I}_{\mathrm{rms}}\right)$ has a value less than the interturn fault between position No. 1 and No. 2.

On the other hand, by increasing only the length of fault gap (step 2 and step 3 respectively) and not the position of fault (position of fault is No. 1) as shown in Fig. 3(c), Fig. 3(e) and Table 1, it can be seen that the obtained root mean square current $\left(\mathrm{I}_{\mathrm{rms}}\right)$ is significantly increased and more than the length of fault gap as step 1. Similarly, for the other position of fault, the root mean square current $\left(\mathrm{I}_{\mathrm{rms}}\right)$ is also significantly increased in comparison with the length of fault gap as step 1; this is the same behavior as the position of fault as No. 1 but the amplitude of fault current is less than the other.

After analyzing the interturn fault current in case of no-load, the mechanical load for the experimental setup is also taken into analysis during the interturn fault occurrence in order to study the impact of load. The results are shown in Table 2 while the examples of fault current signals from the experimental setup with various loads are illustrated in Fig. 4.

Considering the data in Table 2, the weight of mechanical load is divided into 4 sizes which are compared with the base case (no-load). By changing only the weight of mechanical load which the interturn fault occurs between position No. 2 and No. 3 (the length of fault gap is step 1), it can be seen that the root mean square current $\left(\mathrm{I}_{\mathrm{rms}}\right)$ tends to increase significantly with the increase of the weight of mechanical load and more than the base case (no-load). To support this assertion, the interturn fault occurring between position No. 2 and No. 4 (the length of fault gap is step 2) is similarly considered as an example; it can be observed that the root mean square current $\left(\mathrm{I}_{\mathrm{rms}}\right)$ has the same behavior as the interturn fault occurring between position No. 2 and No. 3 but the amplitudes of current on each weight are higher than the case of the length of fault gap as step 1.

Table 1. Results of interturn fault current at various fault positions and various fault gaps along on the winding from the experimental setup in case of no load

\begin{tabular}{|c|c|c|c|c|c|c|c|c|c|}
\hline \multirow{3}{*}{ Data } & \multicolumn{8}{|c|}{ Current (A) } \\
\cline { 2 - 10 } & \multicolumn{2}{|c|}{ Fault position No. 1 } & \multicolumn{2}{c|}{ Fault position No. 2 } & Fault position No. 3 & Fault position No. 4 \\
\cline { 2 - 10 } & $1-2$ & $1-3$ & $1-4$ & $2-3$ & $2-4$ & $2-5$ & $3-4$ & $3-5$ & $4-5$ \\
\hline $\mathrm{I}_{\max }$ & 6.083 & 17.083 & 33.75 & 5.917 & 17.083 & 32.500 & 6.000 & 15.417 & 6.000 \\
\hline $\mathrm{I}_{\min }$ & -5.833 & -15.625 & -41.667 & -6.250 & -15.833 & -43.750 & -5.833 & -16.458 & -5.500 \\
\hline $\mathrm{I}_{\mathrm{rms}}$ & 2.842 & 7.774 & 19.428 & 2.632 & 7.842 & 17.300 & 2.276 & 6.814 & 2.704 \\
\hline
\end{tabular}

Table 2. Results of interturn fault current at various fault gaps from the experimental setup in case of different mechanical loads

\begin{tabular}{|c|c|c|c|c|c|c|c|c|c|}
\hline \multirow{2}{*}{ Load } & \multicolumn{10}{|c|}{ Current (A) } \\
\cline { 2 - 11 } & Fault between position 2-3 & \multicolumn{1}{|c|}{ Fault between position 2-4 } & \multicolumn{3}{|c|}{ Fault between position 2-5 } \\
\cline { 2 - 11 } & $\mathrm{I}_{\max }$ & $\mathrm{I}_{\min }$ & $\mathrm{I}_{\text {rms }}$ & $\mathrm{I}_{\max }$ & $\mathrm{I}_{\min }$ & $\mathrm{I}_{\text {rms }}$ & $\mathrm{I}_{\max }$ & $\mathrm{I}_{\min }$ & $\mathrm{I}_{\text {rms }}$ \\
\hline No-Load & 5.917 & -6.250 & 2.632 & 17.083 & -15.833 & 7.842 & 32.500 & -43.750 & 17.300 \\
\hline $0.25 \mathrm{~kg}$ & 7.500 & -7.708 & 4.135 & 18.750 & -16.667 & 8.364 & 31.667 & -37.500 & 16.406 \\
\hline $0.50 \mathrm{~kg}$ & 8.950 & -8.958 & 4.301 & 18.333 & -19.167 & 8.267 & 30.833 & -37.500 & 16.597 \\
\hline $0.75 \mathrm{~kg}$ & 8.750 & -8.958 & 4.841 & 18.750 & -20.000 & 9.097 & 33.333 & -35.000 & 16.643 \\
\hline $1.00 \mathrm{~kg}$ & 10.208 & -10.208 & 5.160 & 20.416 & -18.750 & 10.145 & 30.833 & -37.500 & 16.706 \\
\hline
\end{tabular}




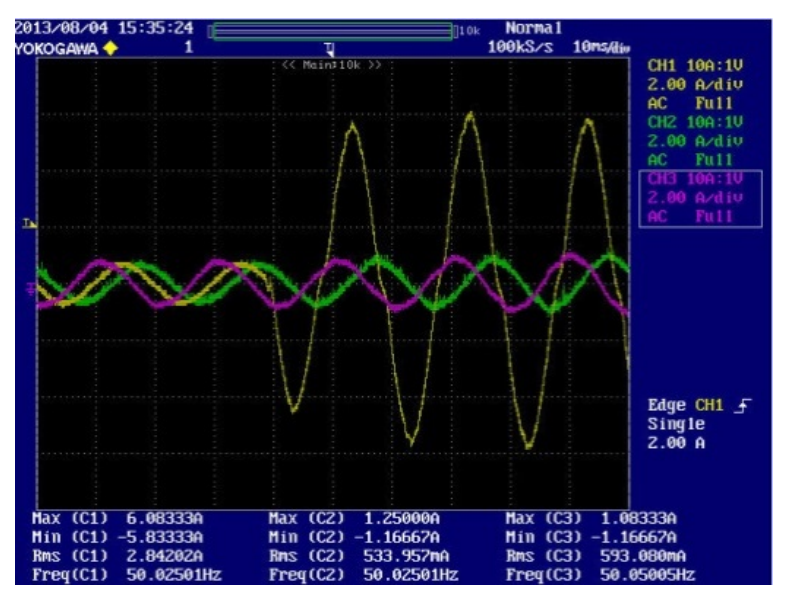

(a) Interturn fault Position 1-2

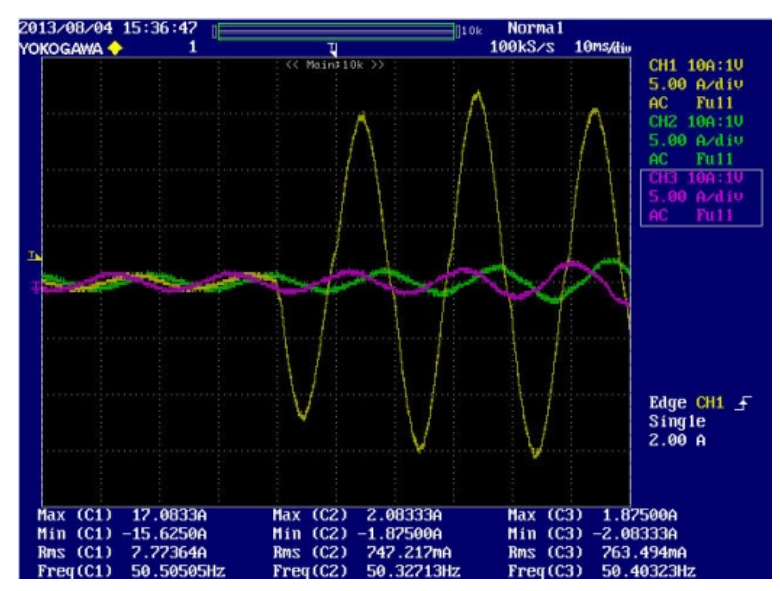

(c) Interturn fault Position 1-3

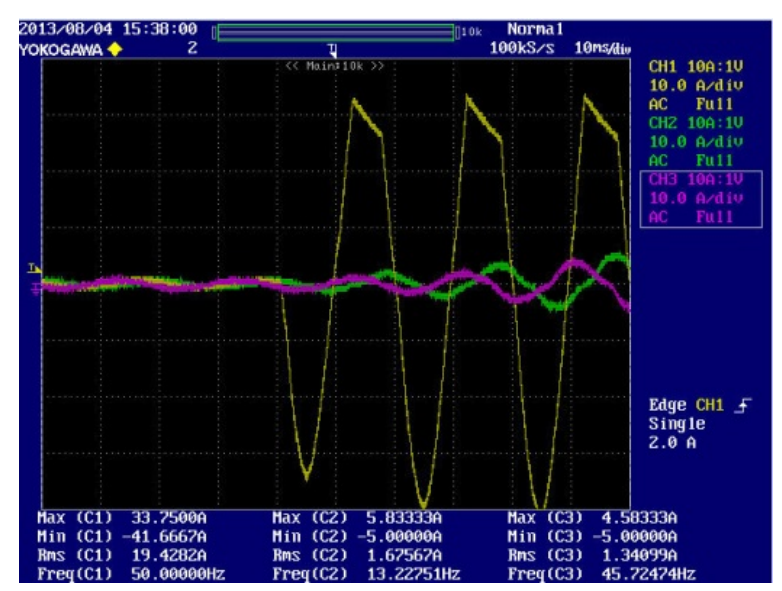

(e) Interturn fault Position 1-4

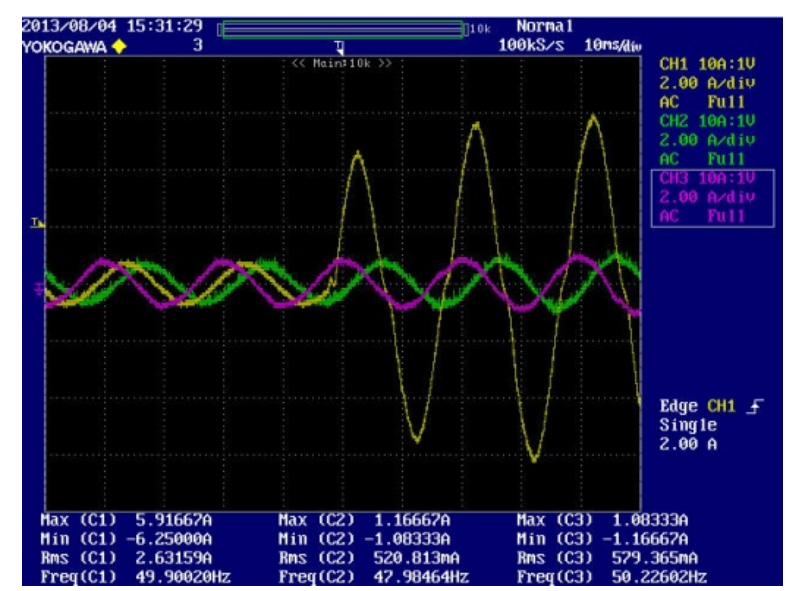

(b) Interturn fault Position 2-3

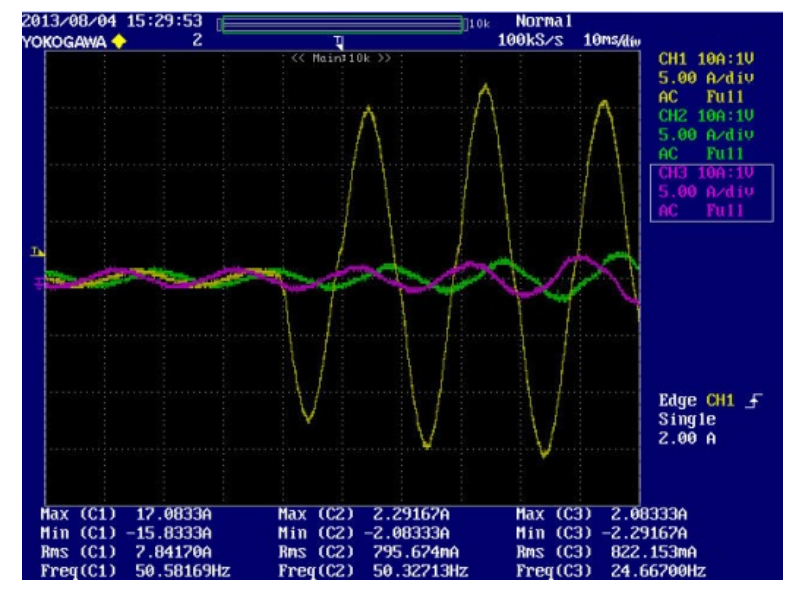

(d) Interturn fault Position 2-4

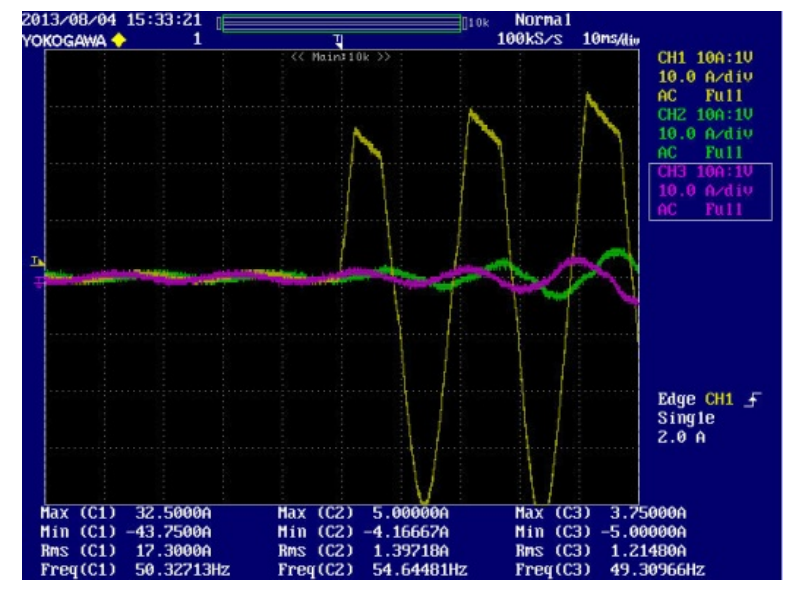

(f) Interturn fault Position 2-5

Fig. 3. Current waveforms captured from oscilloscope for different short turn locations 


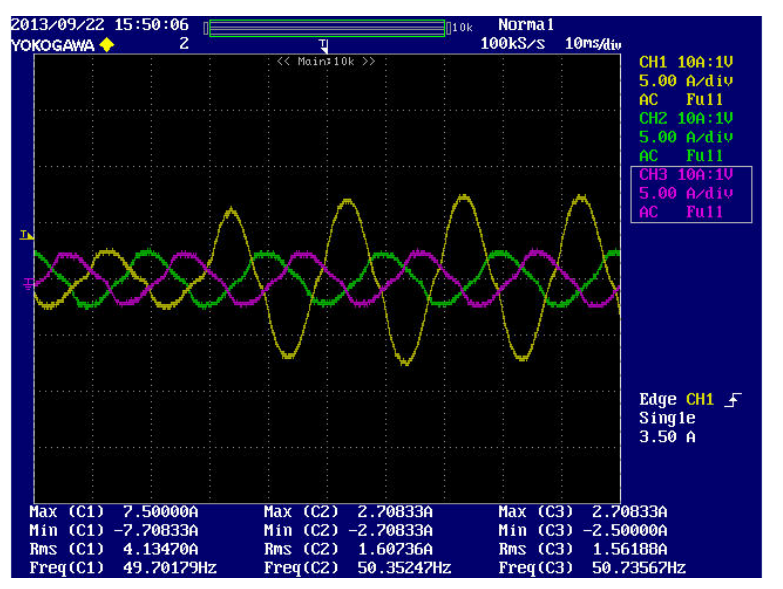

(a) Interturn fault Position 2-3 with light load $(0.25 \mathrm{~kg})$

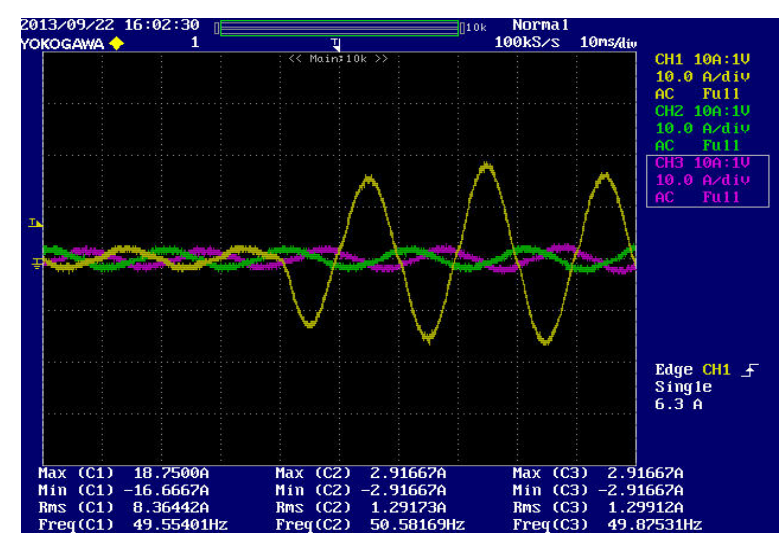

(a) Interturn fault Position 2-4 with light load $(0.25 \mathrm{~kg})$

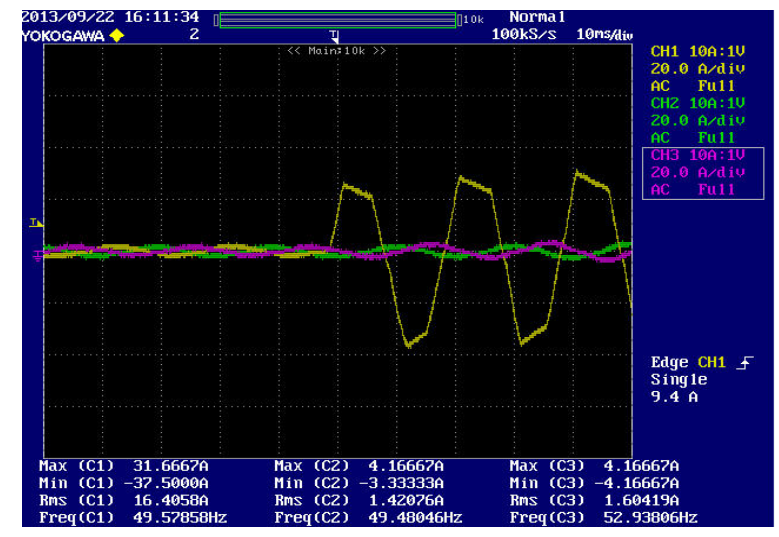

(a) Interturn fault Position 2-5 with light load $(0.25 \mathrm{~kg})$

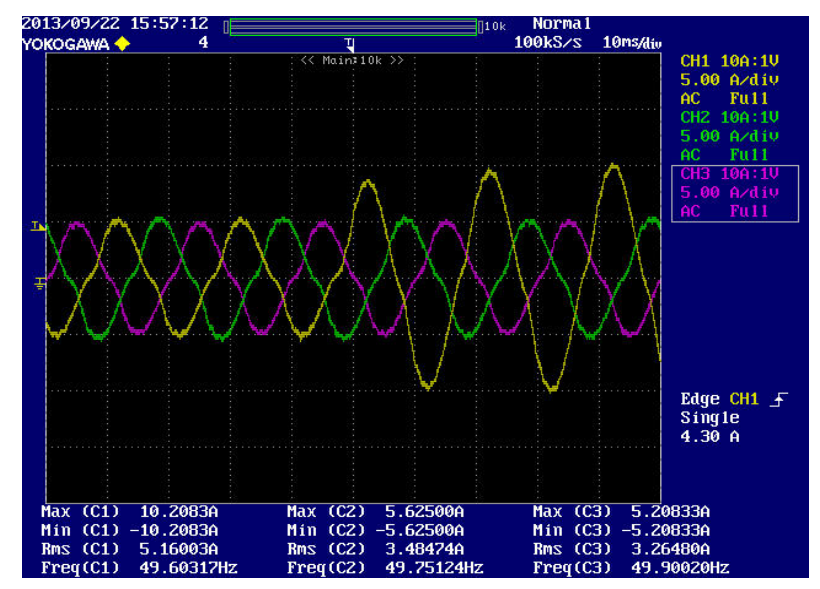

(b) Interturn fault Position 2-3 with heavy load $(1.00 \mathrm{~kg})$

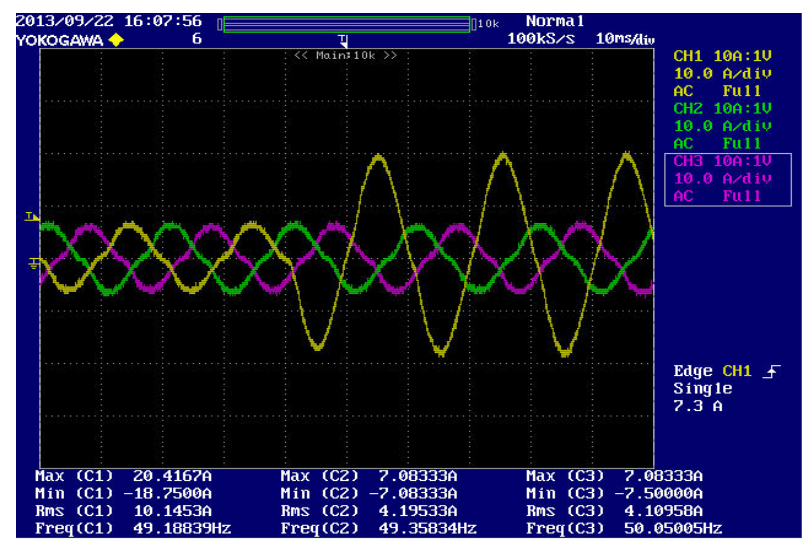

(b) Interturn fault Position 2-4 with heavy load (1.00 kg)

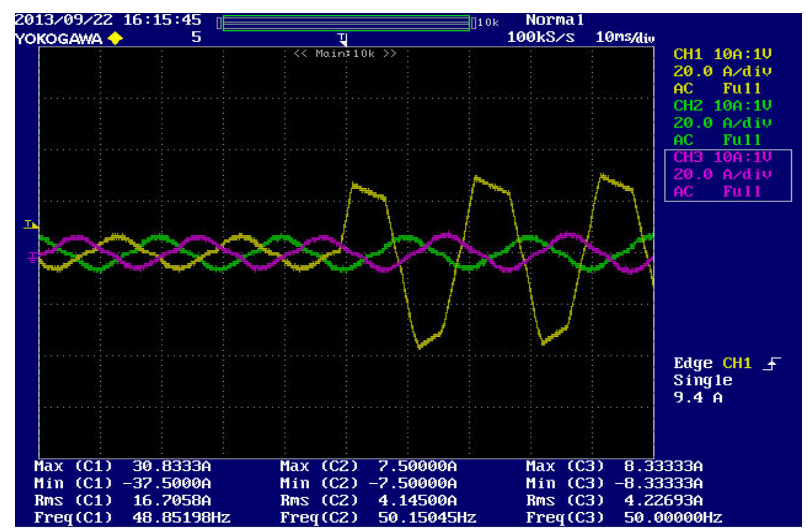

(b) Interturn fault Position 2-5 with heavy load $(1.00 \mathrm{~kg})$

Fig. 4. Current waveforms captured from oscilloscope for different short turn locations with various loads

\section{Conclusions}

This paper presented the behavior of interturn fault on stator winding of induction motor. The fault signal was obtained from the experimental setup. The winding of induction motor is divided into 5 positions so that the interturn fault signals can be obtained. The results from interturn fault characteristics study are shown that current waveform during interturn fault has a sudden change and increases in short period of time. In addition, the various case studies were performed by changing the position of fault, the length of fault gap including varying the 
mechanical load. The results can be summarized as follows:

- By considering the position of fault in case of no-load, the obtained root mean square current $\left(\mathrm{I}_{\mathrm{rms}}\right)$ tends to slightly decrease with the increase of the fault position.

- By considering the length of fault gap in case of no-load, the obtained root mean square current $\left(\mathrm{I}_{\mathrm{rms}}\right)$ tends to significantly increase with the increase of fault distance between two turns when the position of the second defective turn is moved onto the winding.

- By changing the weight of mechanical load and not the position of fault, the obtained root mean square current $\left(\mathrm{I}_{\mathrm{rms}}\right)$ tends to slightly increase with the increase of the weight of mechanical load, and in comparison with the case of no-load, the obtained root mean square current $\left(\mathrm{I}_{\mathrm{rms}}\right)$ has a value more than the base case (no-load).

Finally, the results obtained from the analysis will be beneficial in the development of the fault detection scheme.

\section{References}

(1) F. Babaa, A. Khezzar, M. Boucherma, and A. L. Nemmour : "Condition monitoring of stator faults in induction motors : Part II- A more sensitive indicator of inter - turn short - circuits fault in stator windings under unbalanced supply voltage”, International Aegean Conference on Electrical Machines and Power Electronics, pp. $211-216,2007$.

(2) S. Nandi, H. A. Toliyat, and X. Li : "Condition monitoring and fault diagnosis of electrical motors-a review", IEEE Transaction Energy Conversion, Vol. 20, No. 4, pp.719-729, 2005.

(3) A. Bellini, F. Filippetti, C. Tassoni, and G. A. Capolino: "Advances in diagnostic techniques for induction machines", IEEE Transactions on Industrial Electronics, Vol. 55, No. 12, pp. 4109-4126, 2008.

(4) M. Sahraoui, A. Ghoggal, S. E. Zouzou, A. Aboubou and H. Razik : "Analytical Study, Modeling and Detection of Inter - Turn Short Circuits in Stator Windings of Induction Motors", International Review on Electrical Engineering, Vol.2, No.5, pp. 711-722, 2007.

(5) R.P. Panadero, M.P. Sanchez, M.R. Guasp, J.R. Folch, E. H. Perez, and J.P. Cruz : "Improved Resolution of the MCSA Method Via Hilbert Transform, Enabling the Diagnosis of Rotor Asymmetries at very Low Slip",
IEEE Transaction on Energy Conversion, Vol.24, No.1, pp. 52-59, 2009.

(6) P. Arumugam, T. Hamiti, C. Brunson, C. Gerada : "Analysis of Vertical Strip Wound Fault-Tolerant Permanent Magnet Synchronous Machines", IEEE Transactions on Industrial Electronics, Vol. 61, No. 3, pp. 1158-1168, 2014.

(7) Bon-Gwan Gu, Jun-Hyuk Choi, In-Soung Jung : "Development and Analysis of Interturn Short Fault Model of PMSMs With Series and Parallel Winding Connecting", IEEE Transactions on Power Electronics, Vol. 29, No. 4, pp. 2016-2026, 2014.

(8) K.N. Gyftakis, J.C. Kappatou : "The Zero-Sequence Current as a Generalized Diagnostic Mean in $\Delta$-Connected Three-Phase Induction Motor", IEEE Transactions on Energy conversion, Vol. 29, No. 1, pp. 138-148, 2014.

(9) Abhisek Ukil, Shuo Chen, Andrea Andenna : "Detection of stator short circuit faults in three-phase induction motors using motor current zero crossing instants", Electrical Power Systems Research, Vol. 81, No. 4, pp. 1036-1044, 2011.

(10) Manjeevan Seera, Chee Peng Lim, Dahaman Ishak, Harapajan Singh : "Offline and online fault detection and diagnosis of induction motors using a hybrid soft computing model", Applied Soft Computing, Vol. 13, No. 12, pp. 4493-4507, 2013.

(11) L.E. Negrete Navarrete, M.A. Fonseca Badillo, A. Gonzalez Parada, A. Castaneda Miranda : "Simulation of emerging faults in electric machines", Procedia Engineering, Vol. 35, pp. 41-49, 2012.

(12) Chinmaya Kar, A.R. Mohanty : "Vibration and current transient monitoring for gearbox fault detection using multirresolution Fourier transform", Journal of Sound and Vibration, Vol. 311, No. 1, pp. 109-132, 2008.

(13) O.A. Syggeridou, M.G. Ioannides : "Induction motor's faults detection and diagnosis by using Dedicated Software", Journal of Materials Processing Technology, Vol. 181, No. 1, pp. 313-317, 2007.

(14) M. Manana, A. Arroyo, A. Ortiz, C.J. Renedo, S. Perez, F. Delgado : "Field winding fault diagnosis in DC motors during manufacturing using thermal monitoring", Applied Thermal Engineering, Vol. 31, No. 5, pp. 978-983, 2011.

(15) Yasser Gritli, Andrea Stefani, Claudio Rossi, Fiorenzo Filippetti, Abderrazak Chatti : "Experimental validation of doubly fed induction machine electrical faults diagnosis under time-varying conditions",

(C) 2014 The Institute of Industrial Applications Engineers, Japan. 
Electric Power Systems Research, Vol. 81, No. 3, pp. 751-766, 2011.

(16) Yaw D. Nyanteh, Sanjeev K. Srivastava, Chris S. Edrington, David A. Cartes : "Application of artificial intelligence to stator winding fault diagnosis in Permanent Magnet Synchronous Machines", Electric Power Systems Research, Vol. 103, No. 3, pp. 201-213, 2013.

(17) Rasool Sharifi, Mohammad Ebrahimi : "Detection of stator winding faults in induction motors using three-phase current monitoring", ISA Transactions, Vol. 50, No. 1, pp. 14-20, 2011.

(18) Z. Chilengue, J.A. Dente, P.J. Costa Branco : “An artificial immune system approach for fault detection in the stator and rotor circuits of induction machines", Electric Power Systems Research, Vol. 81, No. 1, pp. 158-169, 2011.

(19) Marcos F.S.V. DAngelo, Reinaldo M. Palhares,
Ricardo H.C. Takahashi, Rosangela H. Loschi, Lane M.R. Baccarini, Walmir M. Caminhas : "Incipient fault detection in induction machine stator-winding using a fuzzy-Bayesian change point detection approach", Applied Soft Computing, Vol. 11, No. 1, pp. 179-192, 2011.

(20) Mohammad Rezazadeh Mehrjou, Norman Marium, Mohammad Hamiruce Marhaban, Norhisam Misron : "Rotor fault condition monitoring techniques for squirrel-cage induction machine - A review", Mechanical Systems and Signal Processing, Vol. 25, No. 8, pp. 2827-2848, 2011.

(21) Manjeevan Seera, Chee Peng Lim, Saeid Nahavandi, Chu Kiong Loo : "Condition monitoring of induction motors: A review and an application of an ensemble of hybrid intelligent models", Expert Systems with Applications, Vol. 41, No. 10, pp. 4891-4903, 2014. 